\title{
ICTs in English Learning and Teaching
}

\author{
http://dx.doi.org/10.3991/ijes.v2i4.4016 \\ Athanasios Drigas, Fani Charami, \\ N.C.S.R. 'Demokritos', Athens, Greece
}

\begin{abstract}
A great number of articles have been written about English language teaching and the use of ICTs (Information and Communication Technologies) during the last decade, achieving a laudable outcome. Recent literature has shown that the use of ICTs in the language classroom has a lot to offer to both learners and teachers, with learners enhancing their vocabulary, improving their reading and speaking skills, and with teachers having to hold a double role; the role of the educator and that of the facilitator, while having to cope with complex situations which include lack of training or lack of equipment in the language classroom. In this paper we shall review and present some representative studies on this field during the last decade.
\end{abstract}

Index terms-ICTs, English language learning and teaching, vocabulary, pedagogy, motivation, teacher perspectives.

\section{INTRODUCTION}

Teaching itself is an art. An art which, according to many teachers and researchers, is constantly changing depending on the era we live and teach in. Today, teaching stands before a milestone, a major shift. A shift towards teaching through technology, where, trying to follow our times, we strive to prepare our students to embrace the new world that lies ahead them.

As Ibrahim discusses, Information and Communication Technologies (ICTs) have altered the way we teach and learn, taking education to another level, where a previous teacher centered approach has today become a student centered one. It is a breakthrough by all means which has revolutionized the learning process allowing knowledge to be effortlessly distributed and be able to take place anywhere since according to the "...Distribution of the knowledge and learning' ... 'Any space is a learning space" [1]. Dina et al. discuss that, since our world is constantly changing, so should educational aims and purposes. Computer Assisted Language Learning is today regarded as a critical element that has shifted educational goals from knowledge acquisition to aspects and ways that produce the development of attitudes and intellectual capabilities as well as of further assimilation of knowledge [2].

As Hashemi et al. argue, it is however the responsibility of teachers to ensure that they are first and foremost familiar with the ICT use that is about to take place in their classroom for such assimilation of knowledge to take place on secure grounds. Consequently, the learners' computer skills are to be evaluated along with their web navigation skills and language level. Adding to the above, computer room availability as well as computer per number of students availability will successfully cover the current needs of a teacher's classroom [3].

As Ching Yang et al. and Hismanoglou observe, Internet technology provides teachers and learners with ample resources where learning can be generated interactively through real world situations, student learning possibilities have been found to be increased along with student computer skills and student views that their learning can be promoted and enhanced through communication tools towards autonomy. Along these lines, student learning possibilities are further enhanced when the employment of an ICT tool such as a DVD or an e-mail is a daily component of their lesson. ICT tools should be reinforcing the coursebook, which is the 'main medium' teachers have, in order to bring together a well-found syllabus that will cover all of their students' needs. It is nevertheless the teacher's responsibility once again to make an effort and get liberated from the fear of ICT use in order to achieve a thriving and praiseworthy outcome for foreign language learning [4][5].

Beauchamp et al. discuss that while ICTs have offered teachers and their classrooms new pathways towards language learning, they have also given students the liberty to orchestrate resources, thus, move towards autonomy and be able to devise more dialogic and synergistic approaches in the future, transforming their learning whether that is individual or group work [6].

\section{ICTS AND THE FOUR SKILLS}

\section{A. Listening}

Nachoua reports that the skill of listening is of key significance for English language learners to acquire. It is also a very intricate skill to teach. The concept of pronunciation, whether that is to understand or produce language, also raises problems for non-native speakers. Using CALL (Computer Assisted Language Learning) is a way to motivate language learners to take a dynamic role in their learning instead of acting as passive listeners [7].

Helping learners develop listening skills can be achieved through a variety of multimedia instruments such as digital stories, Mp3 recordings or podcasts.

In Verdugo et al., Digital stories are embraced by children dearly as they combine interactivity, visual aids and repetition, while they enthuse them through their topics. As listening comprehension is difficult to be taught, these stories help children develop this skill effortlessly, through a fun and motivational activity while developing linguistic structure, literacy, vocabulary, sound patterns and prosody which can ultimately lead them to learn the language. Additionally, children are familiarized with the ways one may employ to convey meaning to others using nonverbal communication such as gestures, facial expressions, pitch of voice etc. It is vital to point out that this social experience, as Verdugo et al. characterize it, takes place at the children's own pace as they are allowed to proceed that way. It is also crucial to mention that, notwithstanding the fascinating resources a teacher may find on the Internet, what is brought in class should not exceed 
the children's linguistic level and technological abilities. Furthermore, teachers have to ensure that the Internet environment in which the children learn is secure [8].

In Roussel et al., older learners use Mp3 recordings to increase their understanding on what they listen, with the recordings enabling them to pause and replay the parts they have inadequately understood, regulating their learning, while taking control over their self-regulation strategies which enable learners 'to better handle incoming spoken discourse' [9].

As Rahimi et al. argues, listening provides learners with large amounts of language input. Thus helping students learn the ways through which their mind functions when learning through technology is crucial, as they discover how to control their learning. 'Planning and consciously executing appropriate actions to achieve a particular goal' as Sheorey and Mokhtari (2001) in Rahimi and Katal (2012, p. 1155) state, is what learners need to master in order to acquire language in technology-based environments. Metacognitive strategies will direct each learner to improve himself/herself in the areas they need improvement, in our case, listening. Podcasts are a means through which the listening skill may be simplified and become available to larger groups of population. Through podcasts, the learning outcome can be influenced along with student motivation since they provide students with a selfregulating input flow, respecting each student's pace, helping them surmount any obstacles they feel they have in that area. What is more, students can listen to the input repeatedly if they wish, anytime, anywhere, mastering its content, which could also be authentic input, free of charge, in their own time [10].

\section{B. Speaking}

As English today is regarded as a lingua franca, the skill of speaking has become a skill of paramount significance to acquire.

Güngor et al. present that in an Online Foreign Language Speaking Class, virtual classes are designed having in mind principles of ELT and e-learning along with techniques that raise interaction, integrating vocabulary and use of English, while providing a stress-free environment in order to motivate even taciturn learners participate and produce spoken language. In order for such an outcome to be achieved though, learners must among other characteristics, be open-minded, motivate themselves and have basic technical knowledge. However, while learners are only required to have basic computer skills, on a tutor's level, that proves to be inadequate. The tutor's role, apart from being a transmitter of knowledge and a guide to the whole class, is also that of the facilitator; a multidimensional role including technological and administrative skills in order to avoid problematic situations [11]. As Hashemi explains, the use of Oovoo and Skype apart from enabling users to interact with pre-recorded messages, also provide learners with the option of synchronous chat, allowing the creation of a virtual class of three to six users, depending on the kind of subscription - free or paid respectively. Another benefit provided by these two tools is that learners can benefit from authentic learning experiences rather than their usual routine, which will in turn motivate them to ask for more real communication hence, more chances to internalise language [12].

Waddel suggests another method to enhance students' speaking skill, through the use of digital video. A short film production through the use of WMM (Windows Media Player) which is a very basic programme, proved to enhance creative thinking, flexibility, originality, and elaboration along with inspiration, motivation and confidence to primary school students to use the English language. Additional motivation also emerged from the constant enjoyment students found in producing the film, while improving their technological skills [13]. Gromik discusses that mobile phones are also favouring language learning. Using their video recording feature, students in Japan created 30 second weekly video productions which have been found to increase the amount of words they spoke in a monologue. Thus, allowing learners use their mobile phones for learning purposes serves two goals; producing more creative thinkers, as students experiment with audio and video captures and photos as well as familiarizing students with the use of MALL (Mobile Assisted Language Learning) [14]. Mercer et al. discuss on slightly different tone the fact that computer-based literacy activities can also enhance children's speaking skills by engaging children into the discussion of the topic, allowing them to share their thoughts and interact with their peers, along with making decisions and learning to justify them to their group. That however is a result that requires integration of the literacy activities with the teaching of the speaking and the listening skill [15].

\section{Reading}

Online reading is a task that appears to be necessary for the $21^{\text {st }}$ century students. Therefore, the creation of a Web-based reading program called 'English Reading Online' was created to narrow the gap between reading and comprehension using online reading strategies. The effective use of reading strategies is known to amplify a reader's understanding. As technology has penetrated our lives, the perception of reading for comprehension through technology has to turn into a forward-thinking way of doing so. As Harrison and Singhal argue in Huang, Chern and Lin, "the ultimate goal is to enable students use strategies spontaneously", thus gain a better understanding of what is being read. Notwithstanding reading strategies having several benefits, there are several limitations such as the level of the participants, the classroom settings and the categorization of strategies which have to be taken into consideration before engaging into practice [16].

Strategic reading instruction benefits all students even those of academic level.

Dreyer et al., in their article argue that even university students come unaware that they should use reading strategies in order to comprehend texts better; unaware of what is expected of them. This perhaps is a result of insufficient high school preparation or little preparation during their time as students. As students gain a lot from reading through strategies which improve their academic performance, having it offered through a technology-enhanced environment multiplies its effect on comprehension while it allows them to learn how to use technology. According to the article, the resources offered to the students through a Learning Content Management System (LCMS) called "Varsite"' allowed them instant access to a larger variety of texts of those found in the University library. This significantly provides each student with the autonomy to access these resources according to their schedule, enabling them to monitor their learning even better [17]. 
PAPER

ICTS IN ENGLISH LEARNING AND TEACHING

Castek et al report that the development of literacy skills is a matter that stresses students a lot. Online adventure reading is a way to take all that stress away and turn it into enjoyment. Students today have this magic tool - the Internet, which can motivate them and help them improve their literacy skills. Also, encouraging students to visit online book clubs and interact with other readers enhances their critical thinking and provides them with skills and strategies which will enable them to make the most of the ICTs available to them. It is of course important to feel relaxed when doing so, hence to know how to use this new tool, not to see this as a convoluted experience, to enjoy collaboration and problem solving and to have positive prior experience on these topics. Students with negative experiences are more likely to gain less from this process. Developing positive disposition in the direction of technology will build a relationship between the learners and reading and writing which will allow them to increase their opportunities on every aspect of their lives in our world today which is an 'information-centered' one[18].

Larson suggests that e-books are an appealing and intriguing method to introduce reading to students in a classroom. Since today's classrooms are constantly changing through the use of technology, e-book reading could assist comprehension of texts through the potential they can offer, introducing students to a wide variety of reading material. As Kindle is the tool used in this study, it was found that it endorsed the integration of traditional and modern literacy skills significantly. As discussed in the article, the two participating students showed different needs, fully met through a different individualized approach. One student showed "deep transactions with the text" "while the other "struggled to understand the emerging plot or specific text features'. For the second student, the use of tools such as the dictionary available enabled her to better understand bigger or unknown words, while changing to bigger fonts also facilitated her effort. Digital readers support both struggling and non struggling readers as this article finally argues [19].

Struggling readers face difficulty in the area of reading comprehension while graduating school for many of them seems unattainable. Sternberg et al. discuss about the action that policymakers could take into consideration in order to help today's adolescents achieve higher goals regarding their education through the use of technology. This action can be translated into seven areas which are a) state-offered virtual courses and delivery systems, b) communication tools, c) artificial intelligence, d) word processors, e) new literacies practices, f) professional development and $\mathrm{g}$ ) technology for parents. The article concludes stating that professionals in the educational field should commit to research so as to minimize the crisis that has surrounded adolescent literacy today [20].

\section{Writing}

Writing can be perplexing for many students since it requires correct use of grammar. Unlike spoken language, written language cannot use gestures or body language to explain what it is that needs to be understood or conveyed. Yusof et al. performed a study where they tried to identify the best way a teacher can use to teach the Passive Voice phenomenon. They used three types of classes. The first was 'the traditional-face to face way', the second was the 'integrative way' where both traditional teaching and web- based teaching were employed and the third type was the 'web-based way' where the only kind of teaching and materials were web-based What they found was that the integrated way proved to be the most beneficial for the learners, as well as that gender plays a non-significant role since the results were not dissimilar. It was also found that the level of the students changed towards improvement after the use of the integrated method, thus results of the post-test significantly differed from the results of the pretest. This study allows us to see that educators should use web-based material as they do improve their students' level using a free and easy to use tool [21].In their articles, Arslan et al, Lomicka et al. and Miyazoe et al. discuss the use of blog software and Tweeter are tools that can help students practice written language, engage with the language they wish to learn and of course to share their thoughts or feelings and reflect on them. Promoting writing instruction through such an entertaining way enables more production of written language which might not have been produced otherwise. Students who also blogged rather than merely attending an in-class session showed better results from those who only received in-class writing instruction. Teachers should make use of this tool as it enhances writing performance while it is not limited within school walls as it can take place anywhere. The result the students who blogged seem to have was an improvement over those who did not, which indicates the value of the integration of this tool. Tweeting also seems to be a valuable tool to initiate the creation of community bonds, hence allowing the learners find out more about each other and build community bonds. In addition, when implementing forums, blogs and wikis at the same time, this seems to have positive results on students' learning progress since this blended approach allows them to study the differences which may occur in ways of expressing in English when using written language [22][23][24].

Van Leeuwen et al. observed that word processors are another way to help learners use the target language as it motivates them to do so. As ICTs enter our classrooms in the form of tools, they can facilitate this procedure to a great extend. Educators embrace this new tool as it allows students to share and construct knowledge in a place such as a primary school, where even the role of the teacher per se is converted to that of a guide or even a participant. It is however clear that this way of teaching cannot be holistically expected to bear fruit when the student level is that of a beginner, neither that a word processor can replace the teacher when, if anything, it complements it [25]. In spite of their various benefits, as stated in many articles by many researchers, the effectiveness of ICTs in the teaching of writing to learners aged five to sixteen years of age is not saluted by everyone., (Andrews et al. in their article state that there is still room for research to indicate the benefits of the use of ICTs in assisting written composition. It is stated that further research in the form of a "new kind of research... at the cutting edge of interface design in the service of learning' is needed [26].

\section{VOCABULARY}

Mustafa et al. discusses that learning vocabulary has often been accused to be the last care of teachers as it is thought to be taught through reading and listening and perceived as 'incidental learning'. It is profound though that without vocabulary knowledge, learners feel that their understanding of language, whether that is written or spo- 
PAPER

ICTS IN ENGLISH LEARNING AND TEACHING

ken, is inadequate. Trying to alter the direction things have had until now, using online reading tasks to teach vocabulary appears to be of help. Through the use of computers, learners show signs of advancement, building their vocabulary and experiencing learning in different ways, through different methods than the ones they were used to. Moreover, they become motivated; hence their attitude towards learning is positive with the use of computer playing an important role. Adding to that, the Internet which has nowadays become part of our lives can add to vocabulary acquisition since its incorporation in the second language classroom will prove to be a prolific source of new vocabulary, given that the learners are trained and know how to use the Internet for this purpose [27].

In addition, vocabulary learning is also thought to be a boring task to complete by learners as vocabulary building can be a very long process, particularly for learners who have been brought up in today's digitalized world.

Yip et al., conducted research on the matter and showed that between the two groups used for the needs of the research with one being the group that would learn vocabulary through game playing and the other, the group that would learn vocabulary using the traditional face to face learning method, the first showed that playing online vocabulary games allows learners to learn better and be able to remember what they have learnt for longer as well as be able to recall more words than the second group that had no interaction with such games. It is possible that the justification for the first group showing more vocabulary acquisition is that learners are keen on being autonomous, something that the online games provide. Another reason can be the fact that these games are motivating and boost learners' confidence building in them a need for further development, while they provide learners with a less stressful feeling of learning. It is however discussed that adopting such a game for long-term learning needs monitoring from teachers ensuring that learning progress continues to takes place. Thus, the role of teachers is to facilitate as well as to research on the matter, considering extending the impact game playing has today into a more cognitive building issues in order to promote and encourage active learning [28].

According to Dalton et al., vocabulary is the area where instructors seem to be at most in need of assistance. In order to help their students' acquisition of vocabulary, teachers require strategy use and resources as well as tools which will be available to them at any time and will allow their students transform their knowledge into production of written and spoken language, which is not feasible without vocabulary development. In order to achieve this, moving from the old, traditional ways to a digital learning can be of great assistance. The use of technology in learning supports learners, transforming them to strategic learners through its use. Hence, Dalton et al. refer to ten strategies for vocabulary learning through technology instruction. These are as follows.

1. Learn from visual displays of word relationships within text.

2. Take a digital vocabulary field trip.

3. Connect vocabulary and learning with online vocabulary games.

4. Have students use media to express vocabulary knowledge.
5. Take advantage of online word reference tools that are also teaching tools.

6. Support reading and word learning with just-in-time vocabulary reference support.

7. Use language translators to provide just-in-time help for ELs.

8. Increase reading volume by reading digital text.

9. Increase reading volume by listening to digital text with a text-to-speech tool and audio books.

10. Combine language learning and social service.

These strategies will not only help students understand the texts they read or perceive their concepts, they will also serve as metacognitive knowledge on how to apply what they have read and learnt to texts yet to come [29].

Loucky reports that in an effort to help students maximize their vocabulary learning, the use of CBDs (Computerised Bilingual Dictionaries) was examined at Japanese college students learning English as a foreign language. It appears that CBDs offer prompt access to the learner's unknown words assisting lexical processing. Between English major students and Engineering major students, the later seem to learn the CBDs use easier. Finally, it was found that the students with more advanced level of English could use the CBDs easier that those with a lower level [30].

Similarly, learners use CALL (Computer Assisted Language Learning), their performance is of great interest, as is the outcome of their performance, their positive attitude towards language learning. Mahmoudi et al performed a study which showed that there is a positive connection between the students' viewpoint and the outcome of what they have achieved regarding CALL and learning English vocabulary [31].

Utami similarly studied whether CALL is a constructive way to enhance vocabulary acquisition. The study included text, picture and video modalities which were combined with exercises and tests showing that the students who used CALL had a 'significantly high benefit on vocabulary acquisition' without which, language input cannot be understood by language learners hence reading a text and understanding it becomes a very difficult task to complete. Furthermore, it is discussed that along with other factors that make the use of CALL such a productive way to enrich students' vocabulary is the presentation of materials which facilitate 'student active learning' and vocabulary recall [32].

\section{Pedagogy}

In order to comprehend the changes that technologically integrated classrooms have brought to today's ways of teaching and learning, a variety of sources have been employed, such as digital game production, digital storytelling, digital moviemaking, classroom observation, and teacher lesson plans.

As we stand on the milestone of ICTs in the language classroom, it seems that a communicative approach should be preferred to a teacher-centered model since it will enable learners move towards autonomy.

As Zhong et al. state, integrating ICTs into the classroom will result to a technology-induced pedagogy that is consistent with a learner centered approach teachers strive for, hence more interactive classrooms will finally arise [33]. 
PAPER

ICTS IN ENGLISH LEARNING AND TEACHING

Benmayor argues that towards such an interactive classroom, digital storytelling aims to use a culture and experience friendly pedagogy to embrace student technology skills and allow students to share personal experiences by sharing their cultural perceptions, become acquainted with new ways of thinking and express themselves through it [34]. Willett, on the other hand suggests that Digital Production aims to bridge leisure and learning experiences of young people through a pedagogy that includes constructivism, constructionism and situated learning, allowing students to express the knowledge they have gained through the perspective of the producer rather than the one of the consumer. Thus, game designing and game playing can turn into scaffolding, knowledge acquisition and 'informal learning' [35].

Hofer et al. discuss that digital Moviemaking aims to induce PCTK (Pedagogical Content Technology Knowledge) along with powerful and at the same time accessible technology integration. In addition while ensuring the application of academic disciplines and balancing the use of technology with a student-centered pedagogy, it considers the teaching of technology as a process that needs careful handling and requires to be introduced using the appropriate scaffolding [36].

Finally, on a teacher's note, and before discussing Teacher perspectives on the use of ICTs we should look at what Law discusses.

Law suggests that there still is a great distance to be covered before claiming that we can provide our students with fully ICT-integrated classrooms. Notwithstanding PCTK becoming TPCTK (Technological Pedagogical Content Technology Knowledge) in a small period of time, it still does not cover what teachers need in order to incorporate ICTs in pedagogical innovations; cognitive, metacognitive, social and socio-metacognitive capacities. Teacher learning as professional development, needs to embrace the orientation and motivation that will enable educators enter a professional network of innovators and produce pedagogical innovation supporting their original goal, to educate in the $21^{\text {st }}$ century [37].

\section{TEACHER PERSPECTIVES}

$\mathrm{Hu}$ et al. performed a study at an English teaching College in China, where the incorporation of ICTs into their classes was initially greeted by most teachers positively. It was discussed that guiding students towards autonomy would be achieved through the use of new technologies as well as to a more student-centered approach. However, a combination of inadequate ICT skills along with a same wave length pedagogical expertise proved to be a hindrance to this effort, while the enthusiasm the teachers expressed at the beginning decreased due to shortcomings such as support and training shortage. Other than that, lack of investment also augmented the fact that this transformation was discontinued [38].

As Saglam et al. discuss, in another school in Turkey, nine ELT experienced teachers with MA TEFL titles were expected to manage the demand for incorporation of ICTs into their instruction while they had had no formal relevant training in the past. Notwithstanding the many obstacles faced by the teachers, the results were positive concerning educational technology and its function in enriching language teaching while accepting that apart from teachers, students also had training needs. Blending the use of ICTs with the teaching of English promoted the construction of knowledge, lifelong learning, different styles and strategies to students, while supplying students with different needs what they required in order to achieve their goals. Additionally, using ICTs created a motivating environment for students while teachers were able to create new materials for teaching. Finally the article concludes with the fact that '...technology on its own is not a "magical wand" or "a silver bullet." [39].

Gallardo del Puerto et al. discuss that the implementation of ICTs into a language classroom as well the extent of the implementation is quite related to the knowledge or training or attitude teachers have towards their use. It could be therefore suggested that further CALL training could increase ICTs use in classrooms. Instructors do not seem to use computers in order to enhance interaction and communication in their classes even though they believe in these two elements for language acquisition considering them particularly important. However, many teachers would incorporate ICTs more into their lessons presuming that they have received training acquiring technological and administrative skills which will allow them to implement new technologies into their classes and help avoid puzzling situations. Furthermore, it is hoped that proper interactive functionalities will be developed in the future. Finally, the study concludes that technological developments and teacher training in CALL should go 'hand -inhand' and that only when combining technology with pedagogy we can expect successful results [40].

In Joseph and Pramela et al. it is discussed that it is the responsibility of teachers to use all the means in their power to transmit knowledge to their students by using each and every tool appropriately as their role in education is crucial. It is teachers who influence and establish the quality of learning that takes place in a classroom. In order for the teachers to achieve a good quality of teaching -as perceived today- they try to implement new technologies into their classrooms, accepting the challenge of improving their teaching. For this reason, the educational institutes must have first supplied them with the technology required for such advancement. In addition, teachers should be aware of the goals and the objectives of their lesson as well as their students' needs in order to reach efficacious learning outcomes. It is however vital to consider questions such as 'what skills do learners need', 'how should students be taught in relation to ICTs' and 'how should teachers teach' in order to provide the best outcome. In an effort to answer the last question, we should give thought to the fact that the implementation of ICTs in a classroom depends on the teachers' positive attitude towards them. We should moreover consider that teachers are not always familiar with the resources available and that they do not always receive training on the tools they will be expected to use in their classes. The findings of the study conducted by Joseph (2013) in English language classrooms in UAE (United Arab Emirates) showed that both IAT (Institutes of Applied Technology) and SIT (Sharjah Institute of Technology) teachers had a positive attitude towards the use of ICTs in their classes as they appreciated the motivation they offered to their students. It should however be mentioned that while IAT teachers received training on ICTs, SIT teachers did not, with the later having to provide training for themselves. On the same wavelength, in-service teachers from the Bachelor of Education TESL Programme Kebangsaan in 
Malaysia shared their thoughts on ICTs and their implementation in their lesson. Most views were positive, highlighting the motivational value of ICTs for students while there were complaints for classrooms not connected to the Internet or even insufficient labs leading to teaching using the traditional classroom method [41][42].

Hashemi finally reports that although many schools around the world are equipped with computers with Internet access in every classroom, multimedia labs, projectors and everything a teacher would need to transform a lesson into a learning experience for their students through multimedia, it is the teachers who lack guidance as to how to use this equipment and how to implement it into everyday's lesson. Also, the recent advancement of technology has made it even more difficult for teachers to adopt and integrate ICTs in their classrooms. This is translated into an impediment since teachers do not accept or use what they do not know; consequently this is where their negative attitude towards ICTs ensues from. In order for teachers to trust this new current they will first have to understand it, be familiar with it and know how to use it. In the case of India, schools are equipped with technology while teachers have not received equivalent background knowledge to support all the technology they have in their classrooms. Reading between the lines, we understand that even when teachers and schools are provided with state of the art facilities, it is always teachers' attitudes that have to be favouring ICTs use in order to achieve adoption of ICTs in a classroom. Hence, teacher re-training should be planned, in order to provide the teaching staff with the ability to lead the way and research the way in which students can best learn through technology. Furthermore, getting teachers to use the ICTs already existing in their classrooms, will enhance critical and cognitive thinking skills of students, therefore the students will be able to evaluate arguments, analyse problems and apply what they have learnt. Besides, if the use of ICTs is motivational for students, it can be for teachers too. It is crucial that teachers see the implementation of technology into their lessons as better than the earlier practices, while in agreement with their current values, former experiences and needs. Providing that they gain professional development through training programs leading to the acquisition of diplomas, teachers will find an incentive in implementing their new knowledge into their lessons. Moreover, discussing the problems teachers may have in special cooperative sessions shall also minimize all the reasons mentioned above that prevent teachers from feeling comfortable to use ICTs in their classrooms [43].

\section{CONCLUSION}

The use of ICTs in English Language learning and teaching is an area not yet fully explored. Both learners and teachers have a lot to gain by their use as well as to offer. Each aspect of ICTs whether that is online reading, CBDs aiming at vocabulary enhancement or computerbased speaking enhancing literacy activities provide learners of our times with invaluable knowledge, not just language-based but also multimedia-based ones. Additionally, we should not overlook the motivational value ICTs have on children and learners as well as the fact that ICTs have flexibility in their use which allows them to be used with both struggling and non-struggling learners, thus their educational value is multiplied. Teachers on the other hand, have to acclimatize to the idea that their role is constantly changing and that they shall have to gain knowledge of how to use all these new tools. In order for that to be accomplished though, there shall have to be gestures both by schools and governments to offer teachers the opportunities to gain this knowledge and motivate them to do so through the acquisition of certificates, officially proving this newly gained knowledge. It is important that teachers know how to use ICTs in their classes in order to incorporate them into their way of teaching on a regular basis. Allowing our teachers to feel threatened by ICTs will result in the discontinuance of their use. Consequently, perceiving ICTs as an aid, rather than a peril, teachers shall not feel intimidated by their presence in their classrooms, which in every case, is not to make the notion of the 'teacher' an obsolete term in some dictionary in the future. Finally, we shall always regard ICTs as a means through which our students shall become acquainted with the world 'out there', broadening their horizons and realizing that since English is today regarded as a lingua franca, it is not merely the people from English speaking countries they can communicate with; it's rather a medium through which they may communicate with the whole world.

\section{REFERENCES}

[1] A. I., Ibrahim, 'Information \& Communication Technologies in ELT.' Journal of Language Teaching and Research, 1(3), 211-214 (2010).

[2] A. T., Dina, \& S. I., Ciornei, 'The Advantages and Disadvantages of Computer Assisted Language Learning and Teaching for Foreign Languages. Procedia-Social and Behavioral Sciences, 76, 248-252 (2013). http://dx.doi.org/10.1016/j.sbspro.2013.04.107

[3] M., Hashemi, \& M., Aziznezhad, 'Computer Assisted Language Learning Freedom or Submission to Machines?' Procedia-Social and Behavioral Sciences, 28, 832-835 (2011a). http://dx.doi.org/10.1016/j.sbspro.2011.11.152

[4] S. C., Yang, \& Y. J., Chen, 'Technology-enhanced language learning: A case study.' Computers in Human Behavior, 23(1), 860-879 (2007). http://dx.doi.org/10.1016/j.chb.2006.02.015

[5] M., Hismanoğlu, 'The integration of information and communication technology into current ELT coursebooks: a critical analysis.' Procedia-Social and Behavioral Sciences, 15, 37-45(2011). http://dx.doi.org/10.1016/j.sbspro.2011.03.048

[6] G., Beauchamp, \& S., Kennewell, 'Interactivity in the classroom and its impact on learning.' Computers \& Education, 54(3), 759766 (2010). http://dx.doi.org/10.1016/j.compedu.2009.09.033

[7] H., Nachoua, 'Computer-Assisted Language Learning for Improving Students'Listening Skill.' International Conference on Education and Educational Psychology (ICEEPSY 2012), Procedia Social and Behavioral Sciences 69, pp. $1150-1159$ (2012).

[8] D. R., Verdugo, \& I. A., Belmonte, 'Using digital stories to improve listening comprehension with Spanish young learners of English.' Language Learning \& Technology, 11(1), 87-101 (2007).

[9] S., Roussel, \& A., Tricot, 'A tentative approach to analysing listening strategies in CALL.' Procedia-Social and Behavioral Sciences, 34, 193-197 (2012). http://dx.doi.org/10.1016/j.sbspro. 2012.02.038

[10] M., Rahimi, \& M., Katal, 'The role of metacognitive listening strategies awareness and podcast-use readiness in using podcasting for learning English as a foreign language.' Computers in Human Behavior, 28(4), 1153-1161 (2012). http://dx.doi.org/10.1016/ j.chb.2012.01.025

[11] M. A., Güngor \& M. N., Demirbas, 'Action and words in online foreign language speaking class' Conference ICL2010, ICL 2010 Proceedings, pp.1261-1262 (2010).

[12] M., Hashemi, \& M., Azizinezhad, 'The Capabilities of Oovoo and Skype for Language Education.' Procedia-Social and Behavioral Sciences, 28, 50-53 (2011b). $\quad$ http://dx.doi.org/10.1016/ j.sbspro.2011.11.010 
[13] A., Waddell, 'Enhancing English speaking skill through digital video' American Journal of Education Sciences, Vol.1 No.4, pp. 2568-5627 (2011).

[14] N. A., Gromik, 'Cell phone video recording feature as a language learning tool: A case study.' Computers \& Education 58 pp. 223 230, Elsevier Ltd. (2012).

[15] N., Mercer, M., Fernandez, L., Dawes, R., Wegerif, \& C., Sams, 'Talk about texts at the computer: using ICT to develop children's oral and literate abilities.' Reading, literacy and language, $p p$. 81-89, UKLA 2003. Blackwell (2003).

[16] H. C., Huang, C. L., Chern, \& C. C., Lin, 'EFL learners' use of online reading strategies and comprehension of texts: An exploratory study.' Computers \& Education, 52(1), 13-26. (2009). http://dx.doi.org/10.1016/j.compedu.2008.06.003

[17] C., Dreyer, \& C., Nel, 'Teaching reading strategies and reading comprehension within a technology-enhanced learning environment.' System, 31(3), 349-365 (2003). http://dx.doi.org/10.1016/S0346-251X(03)00047-2

[18] J., Castek, J.Bevans-Mangelson, \& B., Goldstone, 'Reading adventures online: Five ways to introduce the new literacies of the Internet through children's literature.' International Reading Association pp. 714-728 (2006)

[19] L. C., Larson, 'Digital Readers: The Next Chapter in E-Book Reading and Response.' The Reading Teacher, 64(1), 15-22. (2010). http://dx.doi.org/10.1598/RT.64.1.2

[20] B. J., Sternberg, K. A., Kaplan, \& J. E., Borck, 'Enhancing adolescent literacy achievement through integration of technology in the classroom.' Reading Research Quarterly 42/3, pp. 416-420 (2007) http://dx.doi.org/10.1598/RRQ.42.3.6

[21] N. A., Yusof \& N., Saadon, 'The Effects of Web-Based Language Learning on University Students' Grammar Proficiency.' The $3^{\text {rd }}$ International Conference on e-Learning ICEL2011, 23-24 November 2011, Bandung, Indonesia, Procedia - Social and Behavioral Sciences 67, pp. 402-408, Elsevier Ltd. (2012)

[22] R. Ş., Arslan, \& A., Şahin-Kızıl, 'How can the use of blog software facilitate the writing process of English language learners?' Computer Assisted Language Learning, 23(3), 183-197 (2010). http://dx.doi.org/10.1080/09588221.2010.486575

[23] L., Lomicka \& G., Lord, 'A tale of tweets: Analyzing microblogging among language learners.' System vol. 40 pp.48-63. Elsevier Ltd. (2012).

[24] T., Miyazoe, \& T., Anderson, 'Learning outcomes and students' perceptions of online writing: Simultaneous implementation of a forum, blog, and wiki in an EFL blended learning setting.' System 38, pp. 185-199, Elsevier Ltd. (2010).

[25] C. A., Van Leeuwen, \& M. A., Gabriel, 'Beginning to write with word processing: Integrating writing process and technology in a primary classroom.' International Reading Association, The Reading Teacher Vol. 60, No. 5pp. 420-429, (2007).

[26] R., Andrews, A., Freeman, D., Hou, N., McGuinn, A., Robinson \& J., Zhu 'The effectiveness of information and communication technology on the learning of written English for 5- to 16-yearolds.' British Journal of Educational Technology, Vol 38 No 2 , pp.325-336 (2007). http://dx.doi.org/10.1111/j.1467-8535.2006. 00628.x

[27] H. R., Mustafa, N., Sain, \& N. Z. A., Razak, 'Using Internet for Learning Vocabulary among Second Language Learners in a Suburban School.' Procedia-Social and Behavioral Sciences, 66, 425431 (2012). http://dx.doi.org/10.1016/j.sbspro.2012.11.286

[28] F. W., Yip, \& A. C., Kwan, 'Online vocabulary games as a tool for teaching and learning English vocabulary.' Educational media international, 43(3), 233-249 (2006). http://dx.doi.org/10.1080/ 09523980600641445

[29] B., Dalton, \& D. L., Grisham, "eVoc Strategies: 10 ways to use technology to build vocabulary.' The Reading Teacher, 64 (5), pp. 306-317. International Reading Association (2011).

[30] P. J., Loucky, 'Using computerized bilingual dictionaries to maximize English Vocabulary learning at Japanese Colleges'. CALICO Journal, 21 (1), pp. 105-129 (2003).

[31] E., Mahmoudi, A., Abdul Samad, Zainab \& A., N. Razak, 'Attitude and students' performance in Computer Assisted English Language Learning (CAELL) for learning vocabulary.' The 8th International Language for Specific Purposes (LSP) Seminar -
Aligning Theoretical Knowledge with Professional Practice. Procedia - Social and Behavioral Sciences, 66, pp. 489 - 498. Elsevier Ltd. (2012).

[32] I. H., Utami, 'The effect of computer assisted language learning (CALL) on vocabulary. Jurnal Interaktif, 3(2) (2012).

[33] Y. X., Zhong, \& H. Z., Shen, 'Where is the technology-induced pedagogy?' Snapshots from two multimedia EFL classrooms. British Journal of Educational Technology, 33(1), 39-52 (2002). http://dx.doi.org/10.1111/1467-8535.00237

[34] R., Benmayor, 'Digital storytelling as a signature pedagogy for the new humanities.' Arts and Humanities in Higher Education, 7(2), 188-204 (2008). http://dx.doi.org/10.1177/1474022208088648

[35] R., Willett, 'Technology, pedagogy and digital production: a case study of children learning new media skills.' Learning, Media and Technology, 32(2), 167-181(2007). http://dx.doi.org/10.1080/1743 9880701343352

[36] M., Hofer, \& K., Owings-Swan, 'Digital moviemaking-the harmonization of technology, pedagogy and content.' International Journal of Technology in Teaching and Learning, 1(2), 102110. (2005).

[37] N., Law, 'Teacher learning beyond knowledge for pedagogical innovations with ICT.' In International handbook of information technology in primary and secondary education (pp. 425-434). Springer US (2008).

[38] Z., Hu, \& I., McGrath, 'Innovation in higher education in China: are teachers ready to integrate ICT in English language teaching?; Technology, Pedagogy and Education, 20(1), 41-59 (2011). http://dx.doi.org/10.1080/1475939X.2011.554014

[39] A. L. G., Saglam, \& S., Sert, 'Perceptions of In-Service Teachers Regarding Technology Integrated English Language Teaching.' Online Submission. (2012).

[40] F., Gallardo del Puerto, \& E., Gamboa, 'The evaluation of computer-mediated technology by second language teachers: collaboration and interaction in CALL.' Educational Media International, 46(2), 137-152. (2009). http://dx.doi.org/10.1080/09523980 902933268

[41] R., Joseph, 'Teachers' views of ICT in EL classrooms in UAE Institutes of technology.' (Doctoral dissertation, American University). (2013).

[42] K., Pramela, \& A. Z., Noraza, 'Teachers and the new ict challenges.' Jurnal e-Bangi, 2(2), 1-13. (2007).

[43] B., Hashemi, 'The investigation of factors affecting the adoption if ICTs among English language teachers in ESL context.' International Journal of Language Learning and Applied Linguistics World, 58

[44] (2013).

\section{AUTHORS}

Athanasios Drigas is a Senior Researcher at N.C.S.R. Demokritos. He is the Coordinator of Telecoms Lab and founder of Net Media Lab since 1996. From 1985 to 1999 he was the Operational manager of the Greek Academic network. He has been the Coordinator of Several International Projects, in the fields of ICTs, and e-services (elearning, e-psychology, e-government, e-inclusion, eculture etc). He has published more than 240 articles, 7 books, 25 educational CD-ROMs and several patents. He has been a member of several International committees for the design and coordination of Network and ICT activities and of international conferences and journals. (e-mail: dr@iit.demokritos.gr)

Fani Charami is an English language teacher, currently with N.C.S.R. 'Demokritos', Institute of Informatics and Telecommunications, Telecoms Lab - Net Media Lab, Agia Paraskevi, 153 10, Athens, Greece (e-mail: phaidra_elt@yahoo.com)

Submitted 08 July 2014. Published as resubmitted by the authors 25 October 2014. 